\title{
Weed Management and Productivity of Bread Wheat as Affected by Seed Rates and Herbicides Application at Holeta Ethiopia
}

\author{
Bogale Ayana * $1 \quad$ Zeleke Wondimu $^{2}$ Kassahun Zewdie ${ }^{1}$ \\ 1.Ethiopian Institute of Agricultural Research, Holeta Agricultural Research Center, P.O. BOX 2003, Addis \\ Ababa, Ethiopia \\ 2.Jimma University College of Agriculture and Veterinary Medicine, P.O. BOX 307, Jimma , Ethiopia
}

\begin{abstract}
Wheat is one of the most important food security crops which is cultivated from small to large scale farms in Ethiopia. However, its productivity has been limited due to various abiotic and biotic factors including weeds. The aim of the study was to investigate the effects of seed rates and post emergence herbicides application on weed management and productivity of wheat. Factorial combinations of three levels of seed rates $(100,150$ and $200 \mathrm{~kg}$ $\mathrm{ha}^{-1}$ )and four types of herbicides (Agro 2,4-D $720 \mathrm{~g} / \mathrm{L} 1 \mathrm{lt} \mathrm{ha}{ }^{-1}$,Pallas 45 OD $0.51 \mathrm{t} \mathrm{ha}{ }^{-1}$,Derby $175 \mathrm{SC} 100 \mathrm{ml} \mathrm{ha}^{-1}$ and Lancolet 450 WG $33 \mathrm{gm} \mathrm{ha}^{-1}$ )along with control (a weedy check) were laid out in RCBD with three replications. A total of identified 12 weed species were recorded ( $86 \%$ broad and $14 \%$ grass weeds). Results also revealed that significant effects of seed rate by herbicide interaction for all the traits studied. The minimum weed densities $\left(2.7 \mathrm{~m}^{-2}\right)$ at 45 days after planting, dry biomass of grass weeds $\left(33.33 \mathrm{~kg} \mathrm{ha}^{-1}\right)$ and the highest weed control efficiency (81.22\%) were recorded from the interaction effects of 150 seed rate with Pallas 45 OD while the minimum dry biomass of broad leaf weeds $\left(53.33 \mathrm{~kg} \mathrm{ha}^{-1}\right)$ was recorded at $200 \mathrm{~kg} \mathrm{ha}^{-1}$ seed rate with Lancolet 450 Wattable Granule (WG). The highest number of productive tillers $\left(133.33 \mathrm{~m}^{-2}\right)$,seeds per spike(76.48), thousand grain weight $(44.36 \mathrm{~g})$,grain yield $\left(4516.42 \mathrm{~kg} \mathrm{ha}^{-1}\right)$ and biological yield(13100 kg ha-1) were recorded from the combination of $150 \mathrm{~kg} \mathrm{ha}^{-1}$ seed rate with Pallas 45 OD while the lowest values were observed from the weedy check. Grain yield had strong positive correlations with each of the yield components, however it was negatively correlated with dry weed biomass. Based on partial budget analysis, the maximum net benefit was obtained from the interaction of $150 \mathrm{~kg} \mathrm{ha}^{-1}$ seed rate with Pallas 45 OD but higher number of marginal rate of return was calculated from $150 \mathrm{~kg} \mathrm{ha}^{-1}$ seed rate with 2,4-D . It was also observed that, the combined use of seed rate $150 \mathrm{~kg} \mathrm{ha}^{-1}$ with Pallas $45 \mathrm{OD}$ effectively managed weeds, economical and gave maximum yields, which could be recommended for the test environment. Since the experiment was conducted in one location and for a single season, it should be repeated over seasons or multi locations for best recommendation.
\end{abstract}

Keywords: combination, effect, interaction, maximum, Pallas 45 OD

DOI: $10.7176 / \mathrm{JBAH} / 10-9-04$

Publication date:May $31^{\text {st }} 2020$

\section{INTRODUCTION}

Wheat belongs to the family Poaceae and the genus Triticum which was cultivated under small to large scale farms in Ethiopia. The global annual wheat production is 731.6 million tons from an area of 215.87 million hectares giving an average yield of 3.39 tons ha $^{-1}$ (USDA, 2019). In Ethiopia, it is one of the major staple and strategic food security crops with an average annual production and productivity of 4.64 million metric tons and 2.73 tons ha ${ }^{-1}$ respectively (CSA, 2018). Bread wheat is known to be a major source of energy and protein. Traditionally the crop is used for making Bread, Porridge and other types of foods. The straw is good source for animal feed and also used for thatching roofs (Mathewos et al., 2012).

Although wheat has a great nutritional and economic importance, its productivity has been constrained due to various biotic and abiotic factors. Yield reducing factors in wheat are soil fertility decline, weeds, disease, and insect pests (Bekele et al., 2018). Among the biotic factors weeds are one of the major constraints in wheat production as they reduce productivity due to competition, allelopathy and by providing habitats for pathogens as well as serving as alternate host for various insects, fungi and increase harvest cost ( Haile and Girma,2010). The yield loss assessment conducted in Ethiopia suggested that there is an average yield reduction up to $36 \%$ due to weed competition (Rezene 1986; Hailu et al., 1991). Tanner and Giref (1991) also found that weeds are a significant threat to wheat production in Ethiopia, causing yield loss of up to $70 \%$ in some growing seasons.

In Ethiopia, where wheat is cultivated, poor weed management, indefinite and below optimum plant population used by the farmers appear to be the major limiting factors resulting in low productivity of wheat (Zegeye et al., 2001). In most cases, wheat is grown in the country without appropriate seed rate, sometimes farmers use below optimum seed rate that resulted in poor stand establishment encouraging growth of weeds (Abdulkerim et al., 2015).On the other hand, use of higher seeding rate may exacerbate problems like lodging, insect and disease infestation and damage that harm crop yield (Merga and Ahmed, 2019 ).

Seeding rate, percent viability and germination of seeds usually determine crop density. Normally, higher the density of a crop, lower is weed competition and vice-verse (Babu et al., 2017).The crop density however, cannot 
be increased arbitrarily and indefinitely since every crop has an optimum population beyond which intraspecific competition among crop plants may occur. Moreover, economic benefit of using higher seeding rate should also be taken into account. It is also quite important to address plant density with respect to soil fertility, wheat variety, and agro-ecology (Babu et al., 2017).

The weed controlling methods utilized so far are laborious, tiresome and expensive due to increasing cost of labor, draft animals and farm implements at small scale farms in Ethiopia. To date, the use chemical weed control has becoming popular worldwide and in Ethiopia in particular mainly due to scarcity or expensive labor during peak of growing season and relatively the higher weeding cost (Haile and Girma, 2010). However, the choice of most appropriate herbicide, proper time of application and proper dose is an important consideration for lucrative returns (Tigabu and Asfaw, 2016). In addition, continuous use of a single herbicide or herbicides of the same family or mechanism of action eventually resulted in weed resistance, herbicide persistence as well as the buildup of toxic residues in food chain, toxic effects to humans and animals (Birhanu, 1985; Rezene, 1985).

Previous studies showed that the application of broad spectrum herbicides decreased dry weight of weeds significantly compared to dry weight in non-treated plots and increased yield components and grain yield of wheat (Akhtar et al., 1991; Ahmed et al., 1993). Several researches have been done for the control of broadleaf weeds by application of hand weeding 2, 4-D, Pallas 45 OD, Derby 175 SC and other post emergence herbicides for broad leaf weed management of wheat in Ethiopia (Megersa et al.,2017; Zahara and Shigute,2017;Bekele et al.,2018). Frehiwot et al. (2012) reported that the application of Pallas 45 OD $20 \mathrm{~g} \mathrm{ha}^{-1}$ reduced the dry weight of serious grassy weeds on bread wheat. However, limited applicable technology has been adopted to control grass weed species in wheat. Hand weeding failed to control most grasses especially wild oat which resembles the crop at early stage of growth and caused the greatest yield loss as they compete with the wheat crop throughout the growing season which was difficult to apply for large scale farms. Hence, the introduction of any weed management technology which is economically and agronomically feasible should be investigated for the management of weeds wheat. Further, the yield loss estimation and economic advantages of using appropriate seed rate for better weed management and gaining higher yield not well practiced by most of small scale farms in Ethiopia. However, studies on seed rates in relation with broad spectrum herbicides on various broad leaf and grass weed species management to increase the productivity of wheat remains limited in Ethiopia. Therefore, the aim study of this study was to evaluate the effects of different levels of seed rates and herbicide types on weed management and productivity of wheat (var. Dendea) at Holeta Ethiopia.

\section{MATERIALS AND METHODS}

\section{Description of the study area}

Field experiment was conducted during the 2018/19 main cropping season under rain fed conditions at Holeta Agricultural Research Center. Holeta is located $33 \mathrm{~km}$ west of Addis Ababa at an elevation of 2400 m.a.s.1 and within the geographic coordinates of $9^{\circ} 00^{\prime} \mathrm{N}$ and $38^{\circ} 30^{\prime} \mathrm{E}$. The area receives annual rain fall of $1144 \mathrm{~mm}$ with mean minimum and maximum temperatures of $6^{\circ} \mathrm{C}$ and $22^{\circ} \mathrm{C}$ respectively (EIAR,2018). The soil of the experimental field is clay loam with $\mathrm{p}^{\mathrm{H}}$ of 6.65 , organic carbon $(2.26 \%)$, available Phosphorus $\left(14.17 \mathrm{mg} \quad \mathrm{kg}^{-}\right.$ $\left.{ }^{1}\right)$,total nitrogen $(0.12 \%)$ and cation exchange capacity of $\left(17 \mathrm{Cmol} \mathrm{kg}^{-1}\right)(\mathrm{EIAR}, 2018)$. The edaphic and climatic conditions observed during the trial period were favorable for the exuberant growth of numerous weed species that competed with the crop plants. The climatic conditions observed during the trial period mean rain fall of 1114.5 $\mathrm{mm}$ relative humidity $78.8 \%$ with mean minimum and maximum temperatures of $8^{\circ} \mathrm{C}$ and $25.2^{\circ} \mathrm{C}$, respectively. Experimental materials

The experimental materials used in the experiment were popular bread wheat variety Dendea and four types of broad leaf herbicides that were registered in Ethiopia for the control of annual broad leaf weeds (Table 1).

Table 1.Trade name, common names, rate and mode of action of herbicides used for study (MoANR, 2017).

\begin{tabular}{llll}
\hline Herbicides trade name & Common name & Rate $^{-1}$ & Mode of action (Spectrum of herbicides) \\
\hline Agro 2,4 D 720 g/l & 2,4-D & 1L & $\begin{array}{l}\text { Systemic herbicide for the control of broadleaf } \\
\text { weeds in wheat, barley, teff, maize and sorghum }\end{array}$
\end{tabular}

Pallas 45 OD $\quad$ Pyroxulam $\quad 0.5 \mathrm{~L}$

Systemic herbicide for the control of grass weeds wild oat, downy brome (Bromus Spp.) and annual broadleaf weeds on wheat and tef.

\begin{tabular}{|c|c|c|c|}
\hline Derby $175 \mathrm{SC}$ & Florasulam & $100 \mathrm{ml}$ & $\begin{array}{l}\text { Systemic herbicide for the control of broadleaf } \\
\text { weeds in cereals }\end{array}$ \\
\hline Lancolet $450 \mathrm{WG}$ & $\begin{array}{l}\text { Florasulam } \\
+ \text { Aminopyrolid }\end{array}$ & $33 \mathrm{gm}$ & $\begin{array}{l}\text { Systemic herbicide for the control of broad leaf } \\
\text { weeds in wheat. }\end{array}$ \\
\hline
\end{tabular}




\section{Treatments and experimental design}

The treatments included factorial combinations of three levels of seeding rates $\left(100,150\right.$ and $\left.200 \mathrm{~kg} \mathrm{ha}^{-1}\right)$ and four types post emergence herbicides (Agro 2,4-D amine 720g/L ,Pallas 45 OD ,Derby 175 SC, Lancolet 450 WG plus weedy check that were laid out in a Randomized Complete Block Design with three replications.

\section{Experimental procedure and crop management}

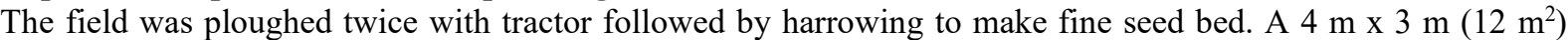
gross plot size was used as the experimental unit accommodating 15 rows of each $4 \mathrm{~m}$ length. Well popularized wheat variety, Dendea was used as a test crop. Seeds were drill planted in rows at $20 \mathrm{~cm}$ spacing between rows on July 17, 2018. The experimental area was fertilized with the recommended rate of $55 \mathrm{~kg} \mathrm{ha}^{-1}$ of N and $182 \mathrm{~kg}$ ha${ }^{1}$ of $\mathrm{P}_{2} \mathrm{O}_{5}$ that were applied in the form of Urea $(46 \% \mathrm{~N})$ and NPS $\left(19 \% \mathrm{~N}, 38 \% \mathrm{P}_{2} \mathrm{O}_{5}, 7 \% \mathrm{SO}_{4}\right)$, respectively. Nitrogen fertilizer was applied at two doses (split application) i. e 2/3 of it was applied at time of sowing by mixing with full dose of Nitrogen and the remaining 1/3 was applied at tillering stage. Herbicides were applied at post emergence stage (30 DAE ) with the help of knapsack sprayer nozzle size of 350 um while the volume of water was $200 \mathrm{~L} / \mathrm{ha}^{-1}$ pressurized at $40 \mathrm{psi}$. All other management practices were uniformly applied to all plots as per the recommended practices.

\section{Data collection}

Weed species identification was made by uprooting fresh weeds from experimental field and taken to laboratory. After the weed flora were identified, they were categorized as grasses and broad leaf weeds using reference of manuals, consulting experienced professionals and comparing with existed herbarium as described by Stroud and Parker (1989). Data regarding the kind of weed species and their densities were counted at 25 day after sowing i. $\mathrm{e}$, before the application of herbicides by using four quadrates with sizes of $0.25 \mathrm{~m} \times 0.25 \mathrm{~m}$ randomly placed in each plot and their density was calculated $\mathrm{m}^{-2}$. In addition, individual weed species density count was also done at 45 days after herbicides were applied by randomly placing four quadrates of sizes $0.25 \mathrm{~m} \times 0.25 \mathrm{~m}$ converted to $\mathrm{m}^{-2}$.The density of each weed species in the field was counted after treatment by randomly placing of four quadrat of sizes $25 \mathrm{~cm} \times 25 \mathrm{~cm}$ in each plots and calculated $\mathrm{m}^{-2}$ basis. The relative weed density was calculated by the formula (Marwat et al., 2013), RWD(\%) $=\frac{\text { Number of weeds of a species }}{\text { total number of weeds }} X 100$ The aboveground dry biomass of grass weeds and dry biomass of broad leaf weeds harvested from each quadrat placed into paper bags separately and oven drying at a $65{ }^{\circ} \mathrm{C}$ for 48 hours and subsequently the dry weights were measured. Weed control efficiency (WCE) was determined by the following formula:

$W C E(\%)=\frac{W D C-W D P}{W D C} X 100$ Where, WCE $=$ Weed Control Efficiency, WDC $=$ Weed Dry weight in Control Plot and DWP $=$ Weed Dry weight in Particular treatment (Davasenapathy et al., 2008).

Numbers of total productive tillers counted from five rows with the length of $1 \mathrm{~m}$ randomly taken in each net plot area and was converted into $\mathrm{m}^{2}$ at harvest. Number of seeds per spike was determined from randomly taken 4 spikes per plot. Thousand grains weight was counted from the bulk of threshed produce from the net plot area and their weight recorded. biological yield $\left(\mathrm{kg} \mathrm{ha}^{-1}\right)$ was determined by taking the total weight of the harvest from each net plot area after sun dried the whole aboveground biomass.Grain yield was measured after threshing the sun dried plants harvested from each net plot and the yield was adjusted at $12.5 \%$ grain moisture content (Amare et al., 2014).Harvest index was calculated by dividing grain yield per plot by the total aboveground dry biomass yield

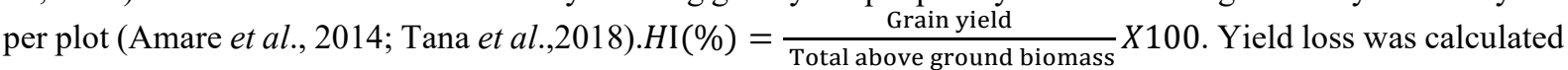
by subtraction of grain yield of particular treatment from maximum grain yield from treatments divided by maximum grain yield from treatments(Amare et al., 2014).

$$
\mathbf{Y L}(\%)=\frac{\text { Maximum grain yield from treatment-Grain yield of particular treatment }}{\text { Maximum grain yield from treatment }} \times 100
$$

\section{Statistical analysis}

The means of each data was checked by the normality test depending on Shapiro test $(\operatorname{Pr}<\mathrm{W})$ before analysis of variance using the GLM procedure of SAS (SAS 9.3 version). When the treatment effects were significant, means were compared using Fisher's LSD test at 5\% level of significance (Gomez and Gomez, 1984).Correlations between traits were also analyzed using Pearson's correlation coefficients in SAS (Gomez and Gomez, 1984).

\section{Partial budget analysis}

The partial budget analysis was made to determine the economic feasibility of the treatments. It was calculated by taking into account the variable input cost involved and the gross returns obtained from different treatments. The variable cost included the fertilizers, herbicides, seed, labor cost involved for harvesting, threshing and winnowing as their cost varied according to the time, availability of labor and the market price. Actual yield was adjusted downwards to $10 \%$ of the experimental yield to represents the farmer's yield as described by CIMMYT (1988).For determining gross returns, the prevailing local market price Ethiopian birr $1400 / 100 \mathrm{~kg}$ of wheat at the harvest of wheat was considered. The net returns were calculated by subtracting the cost of treatment from the gross returns as $\mathrm{RNR}=\mathrm{GR}-\mathrm{VC}$, where, $\mathrm{RNR}=$ Relative net returns, GR $=$ Gross returns, and VC $=$ Variable cost. Benefit to cost ratio was calculated by dividing gross return to total variable cost. The marginal rate of return was calculated 
by the formula MRR $=\frac{\mathrm{DNI}}{\mathrm{DIC}}$, Where, $\mathrm{MRR}=$ the marginal rate of return, $\mathrm{DNI}=$ difference in net income compared with control and DIC = difference in input cost compared with control as described by CIMMYT (1988).

\section{RESULTS AND DISCUSSION}

Composition of weed flora and density in the experimental field

The weed community comprised of both broadleaf and grass weeds which were classified in to eight major families. Out of total weeds species present in the experimental field $86 \%$ were annual broadleaf weeds while $14 \%$ were annual grasses weeds. The maximum relative weed density in the field was G. pulviflora (22.84\%) followed by $P$. nepalense (18.72\%) while minimum relative weed density was recorded from G. scabra (0.98\%) (Table - 2).

Table 2.Categories of the identified weed species and their densities in the experimental field

\begin{tabular}{|c|c|c|c|c|}
\hline Scientific names & Families & $\begin{array}{l}\text { Weed density } \mathrm{m}^{-2} \\
\text { before spray }\end{array}$ & $\begin{array}{l}\text { Relative Weed } \\
\text { Density }(\%)\end{array}$ & Life form/category \\
\hline Arthraxon prinodes L. & Poaceae & 21.06 & 5.11 & Annual (grass) \\
\hline Setaria pumila L. & Poaceae & 31.33 & 7.59 & Annual (grass) \\
\hline Phalaris paradoxa L. & Poaceae & 5.39 & 1.31 & Annual (grass) \\
\hline $\begin{array}{l}\text { Galinsoga pulviflora } \\
\text { Cav. }\end{array}$ & Compositae & 94.18 & 22.84 & Annual (broad leaf) \\
\hline $\begin{array}{l}\text { Corrigiola capensis } \\
\text { Wild }\end{array}$ & Caryophylaceae & 48.71 & 11.81 & Annual (broad leaf) \\
\hline $\begin{array}{l}\text { Guizotia } \\
\text { scabra(Vis)Chiov }\end{array}$ & Compositae & 4.06 & 0.98 & Annual (broad leaf) \\
\hline $\begin{array}{l}\text { Oxalis corniculata } \\
\text { HBK }\end{array}$ & Oxalidaceae & 28 & 6.77 & Annual (broad leaf) \\
\hline Plantago lanceoleta $\mathrm{L}$. & Plantaginaceae & 19.1 & 4.62 & Annual (broad leaf) \\
\hline $\begin{array}{l}\text { Polygonum nepalense } \\
\text { L. }\end{array}$ & Polygonaceae & 77.2 & 18.72 & Annual (broad leaf) \\
\hline $\begin{array}{l}\text { Raphanus } \\
\text { raphanistrum L. }\end{array}$ & Brassicaceae & 15.5 & 3.76 & Annual (broad leaf) \\
\hline Spergula arvensis L. & Caryophylaceae & 20 & 4.85 & Annual (broad leaf) \\
\hline $\begin{array}{l}\text { Cyanotis barbata } \\
\text { D.Don }\end{array}$ & Commelinaceae & 47.7 & 11.57 & Annual (broad leaf) \\
\hline
\end{tabular}

The result indicated that variation of weed flora composition could be depending on amount of weed seed bank in the soil, germination capacity and favorable environmental conditions. Abraham (2006) also reported that weed growth, population density and distributions in cereal fields vary from place to place depending upon soil and climatic factors and management practices.

The effects of seed rates and herbicides on weed density at 45 days after herbicides application in bread wheat

The main effects of seed rates and herbicides application as well as their interaction were significant on weed density at 45 DAP.The combined effects of $150 \mathrm{~kg} \mathrm{ha}^{-1}$ seed rate with Pallas 45 OD showed that lowest weed density $\left(2.7 \mathrm{~m}^{-2}\right)$ as compared to any other treatments, whereas the highest weed density count $\left(4.56 \mathrm{~m}^{-2}\right)$ was recorded from the interaction of $100 \mathrm{~kg} \mathrm{ha}^{-1}$ seed rate at weedy check plots (Table - 3).

Table 3.The effects of seed rates and herbicides on weed density $\mathrm{m}^{-2}$ at 45 days after herbicides application in bread wheat

\begin{tabular}{|c|c|c|c|c|}
\hline Herbicides & & Seed rat & & \\
\hline & 100 & 150 & 200 & \\
\hline $2,4-\mathrm{D} 720 \mathrm{~g} / \mathrm{l}$ & & $3.38^{\mathrm{de}}$ & $2.88^{\mathrm{Ghi}}$ & $3.13^{\mathrm{efG}}$ \\
\hline Pallas 45 OD & & $3.05^{\mathrm{fg}}$ & $2.7^{\mathrm{I}}$ & $2.74^{\mathrm{HI}}$ \\
\hline Derby $175 \mathrm{SC}$ & & $3.31^{\mathrm{def}}$ & $2.92^{\mathrm{GHi}}$ & $2.98^{\mathrm{GH}}$ \\
\hline Lancolet & & $3.24^{\mathrm{def}}$ & $3.41^{\mathrm{d}}$ & $3.12^{\mathrm{fg}}$ \\
\hline Weedy check & & $4.56^{\mathrm{a}}$ & $4.2^{\mathrm{b}}$ & $3.93^{c}$ \\
\hline
\end{tabular}

LSD (1\%) 0.26

$\mathrm{CV}(\%) \quad 4.76$

Means followed by the same letter in the upper case with in rows and lower case with in columns are not significantly different from each other at $1 \%$ level of significance

The application of $100 \mathrm{~kg} \mathrm{ha}^{-1}$ seed rate with all herbicides except Pallas 45 OD showed that statistically nonsignificant and also application of $150 \mathrm{~kg} \mathrm{ha}^{-1}$ seed rate with 2,4 - D and Derby $175 \mathrm{SC}$ revealed that statistically no significant difference. Similarly, application of $200 \mathrm{~kg} \mathrm{ha}^{-1}$ seed rate with 2, 4 -D and Lancolet $450 \mathrm{WG}$ revealed that statistically no significant difference. Moreover, the application of $200 \mathrm{~kg} \mathrm{ha}^{-1}$ seed rate with Pallas 45 OD 
and Derby 175 SC revealed that statistically no significant difference. In addition, the application of all herbicides except Lancolet $450 \mathrm{WG}$ with increased seed rates from $100 \mathrm{~kg} \mathrm{ha}^{-1}$ to $200 \mathrm{~kg} \mathrm{ha}^{-1}$ showed that statistically no significant difference.

The result clearly indicated that application of $150 \mathrm{~kg} \mathrm{ha}^{-1}$ seed rate with Pallas 45 OD decreased weed density at 45 days of application. This might be related to lower inter and intra specific competition and herbicides were persistent enough to suppress weeds up to 45 days after treatment and beyond that. Thus, the lack of competition with weeds enabled wheat to close its canopy and dominate weeds throughout the growing season. These results are in line with those of Bibi et al. (2008) who concluded that herbicides significantly affected the weed population per unit area.

\section{Dry biomass of broad leaf weeds at harvest}

The main effects of seed rates, herbicides application and their interaction were significant on dry biomass of broad leaf weeds.The highest dry biomass of broad leaf weeds $\left(490 \mathrm{~kg} \mathrm{ha}^{-1}\right)$ was recorded in weedy check at $100 \mathrm{~kg} \mathrm{ha}^{-}$ ${ }^{1}$ seed rate whereas the minimum $\left(46.67 \mathrm{~kg} \mathrm{ha}^{-1}\right)$ was recorded in combination of $200 \mathrm{~kg} \mathrm{ha}^{-1}$ seed rate with Pallas 45 OD application (Table -4 ).

The application of all herbicides with $150 \mathrm{~kg} \mathrm{ha}^{-1}$ and $200 \mathrm{~kg} \mathrm{ha}^{-1}$ seed rates revealed that statistically no significant difference. Similarly, the application of $100 \mathrm{~kg} \mathrm{ha}^{-1}$ seed rate with all herbicides except Pallas 45 OD produced statistically no significant difference. The minimum dry biomass of broad leaf weeds at $200 \mathrm{~kg} \mathrm{ha}^{-1} \mathrm{seed}$ rate with Pallas 45 OD might be related to the activity of the treatments higher seed rate with broad spectrum herbicides that resulted in less inter and intra-specific competition and also due to the ability of the herbicide in reducing weed density by killing both broadleaf and narrow leaf weeds by affecting the physiological process of those weeds resulted in mortality of weeds that remained in field.

Table 4. The effect of seed rates and herbicides application on dry biomass of broad leaf weeds $\left(\mathrm{kg} \mathrm{ha}^{-1}\right)$ in bread wheat

\begin{tabular}{llll}
\hline Herbicides & \multicolumn{3}{c}{ Seed rates kg ha ${ }^{-1}$} \\
\cline { 2 - 4 } & 100 & 150 & 200 \\
\hline 2,4 D 720 g/1 & $105^{\mathrm{d}}$ & $75^{\mathrm{eF}}$ & $65^{\mathrm{Fgh}}$ \\
Pallas 45 OD & $61.67^{\mathrm{F}}$ & $65^{\mathrm{Fgh}}$ & $46.67^{\mathrm{h}}$ \\
Derby 175 SC & $98.33^{\mathrm{d}}$ & $71.67^{\mathrm{eFG}}$ & $63.33^{\mathrm{h}}$ \\
Lancolet 450 WG & $88.33^{\mathrm{de}}$ & $63.33^{\mathrm{fgh}}$ & $53.33^{\mathrm{gh}}$ \\
Weedy check & $490^{\mathrm{a}}$ & $413.33 \mathrm{~b}$ & $358.33^{\mathrm{c}}$ \\
\hline
\end{tabular}

$\operatorname{LSD}(1 \%) \quad 8.97$

$\mathrm{CV}(\%) \quad 8.97$

Means followed by the same letter in the upper case with in the rows and lower case with in the columns are not significantly different from each other at $1 \%$ level of significance

This result also indicated that the combined use of higher seed rate decreased the growth of weeds by covering the available spaces and resulted in limited weed growth. The lower number of dry weed biomass related to ability of herbicide acting on many broad leaf weed species and also due to minimum number of weed density but the higher number dry broad weed at weedy check could be better higher weed growth. This finding was analogous with Tana et al.(2018) who concluded that the weed dry weight recorded in weed-free treatments of longer duration was reduced than weedy treatments due to the reason that temperature and climatic requirements were not in favor of weed seed germination after the first weeds were removed.

\section{Dry biomass of grass weeds at harvest}

The effect of seed rates, herbicides and their interactions were highly influenced by dry biomass of grass weeds. The interaction of Pallas $45 \mathrm{OD}$ with $150 \mathrm{~kg} \mathrm{ha}^{-1}$ seed rate gave minimum grass weed biomass $\left(33.33 \mathrm{~kg} \mathrm{ha}^{-1}\right)$ followed by interaction of Lancolet $450 \mathrm{WG}$ with $200 \mathrm{~kg} \mathrm{ha}^{-1}$ seed rate $\left(41.66 \mathrm{~kg} \mathrm{ha}^{-1}\right)$. The highest dry weight of grass weed $\left(66.66 \mathrm{~kg} \mathrm{ha}^{-1}\right)$ was obtained from the interaction of $100 \mathrm{~kg} \mathrm{ha}^{-1}$ and $150 \mathrm{~kg} \mathrm{ha}^{-1}$ seed rates at weedy check (Table $-5)$.

Table 5.The effects seed rates and herbicides on dry biomass of grass weeds $\left(\mathrm{kg} \mathrm{ha}^{-1}\right)$ in bread wheat

\begin{tabular}{|c|c|c|c|}
\hline \multirow[t]{2}{*}{ Herbicides } & \multicolumn{3}{|c|}{ Seed rates $\mathrm{kg} \mathrm{ha}^{-1}$} \\
\hline & 100 & 150 & 200 \\
\hline 2,4 D $720 \mathrm{~g} / 1$ & $53.33^{\mathrm{Bc}}$ & $45^{\mathrm{Cd}}$ & $48.33^{\mathrm{bCd}}$ \\
\hline Pallas 45 OD & $48.33^{b c D}$ & $33.33^{\mathrm{E}}$ & $41.66^{\mathrm{dE}}$ \\
\hline Derby $175 \mathrm{SC}$ & $53.33^{\mathrm{bC}}$ & $45^{\mathrm{CD}}$ & $45^{\mathrm{CD}}$ \\
\hline Lancolet $450 \mathrm{WG}$ & $55^{\mathrm{bC}}$ & $45^{\mathrm{CD}}$ & $41.66^{\mathrm{De}}$ \\
\hline Weedy check & $66.66^{\mathrm{A}}$ & $66.66^{\mathrm{A}}$ & $56.66^{\mathrm{Ab}}$ \\
\hline $\operatorname{LSD}(1 \%)$ & & & \\
\hline $\mathrm{CV}(\%)$ & & & \\
\hline
\end{tabular}

Means followed by the same letter in the upper case with in the rows and lower case with in columns are not 
significantly different from each other at $1 \%$ level of significance

The interaction of $100 \mathrm{~kg} \mathrm{ha}^{-1}$ and $200 \mathrm{~kg} \mathrm{ha}^{-1}$ seed rates with all herbicides except for weedy check statistically showed that no significant difference and also the application of $150 \mathrm{~kg} \mathrm{ha}^{-1}$ seed rate with all herbicides except application with Pallas 45 OD showed that statistically no significant difference. The application of all seed rate with 2,4-D, Derby $175 \mathrm{SC}$ and Lancolet $450 \mathrm{WG}$ produced statistically no significant difference. The lowest number of dry biomass of grass weeds at $150 \mathrm{~kg} \mathrm{ha}^{-1}$ seed rate with Pallas $45 \mathrm{OD}$ due to reducing the density of weeds and also suppressed the weed growth consequently resulted in lower dry weight. Lower weed dry weight in plots where herbicides were applied can be attributed to low weed density.

This finding was similarly with Nadeem et al.(2006) and Munsif et al.(2009) who concluded that maximum weed density in weedy check can be attributed to unchecked growth, while application of herbicide caused mortality of weed resulting in lower weed density at harvest. Unavailability of nutrients in control and suppression by well-developed wheat plants resulted in similar weed density.

Weed control Efficiency

Weed control efficiency was influenced by seed rates, herbicides application and their interactions .The maximum weed control efficiency was recorded in the interaction of $150 \mathrm{~kg} \mathrm{ha}^{-1}$ seed rate with Pallas 45 OD (81.22\%) followed by $200 \mathrm{~kg} \mathrm{ha}^{-1}$ seed rate with Pallas 45 OD (78.6\%) (Table - 6).

Table 6.The effects seed rates and herbicides on weed control efficiency (\%) in bread wheat

\begin{tabular}{llll}
\cline { 3 - 4 } Herbicides & \multicolumn{3}{c}{ Seed rates kg ha } \\
\cline { 2 - 4 } & 100 & 150 & 200 \\
\hline Agro2,4 -D 720 g/1 & $71.58^{\mathrm{E}}$ & $74.44^{\mathrm{bcdE}}$ & $72.55^{\mathrm{dE}}$ \\
Pallas 45 OD & $77.46^{\mathrm{Abc}}$ & $81.22^{\mathrm{A}}$ & $78.6^{\mathrm{Ab}}$ \\
Derby 175 SC & $72.64^{\mathrm{DE}}$ & $75.15^{\mathrm{bcDE}}$ & $73.76^{\mathrm{cDE}}$ \\
Lancolet 450WG & $72.45^{\mathrm{de}}$ & $76.92^{\mathrm{abCD}}$ & $76.66^{\mathrm{abCD}}$ \\
Weedy check & $0.00^{\mathrm{F}}$ & $0.00^{\mathrm{F}}$ & $1.93^{\mathrm{F}}$ \\
\hline
\end{tabular}

LSD (1\%) interactions $=4.72$

$\mathrm{CV}(\%)$ interactions $=4.68$

Means followed by the same letter in the uppercase with in rows and the same letter in the lower case with in columns are not significantly different from each other at $1 \%$ level of significance

The application of all seed rates with all herbicides except Pallas 45 OD showed that statistically no significant difference. Similarly, the application of $200 \mathrm{~kg} \mathrm{ha}^{-1}$ seed rate with 2, 4-D, Derby $175 \mathrm{SC}$ and Lancolet 450WG revealed that statistically no significant difference. Furthermore, the interaction of increased seed rate $100 \mathrm{~kg} \mathrm{ha}^{-}$ ${ }^{1}$ to $200 \mathrm{~kg} \mathrm{ha}^{-1}$ with all herbicides application showed that statistically no significant difference except for weed check. The higher weed control efficiency at higher seed rate with Pallas 45 OD might be related to lowest dry biomass of weeds which exhibited that the ability of the herbicides killing various weeds species in wheat.

Additionally, the result also revealed that increased seed rate with combination of broad spectrum herbicides increased weed control efficiency due to limited weed growth but at low seed rate decreased in weed control efficiency as a result of severe inter and intra specific competition and higher weed biomass. The use of Pallas 45 OD increased weed control efficiency at all seed rate interaction. This might be related to the activity of broad spectrum of the herbicide against both broad and grassy weeds as compared to other herbicides application. These findings are similar with who reported that herbicides with broad spectrum provided better weed control efficiency than control treatment (Ashiq et al.,2007). Tana et al. (2018) reported that the high control efficiency indicated that the weed were controlled when they are young or before they accumulated more dry matter by competing with the crop plants.

\section{Number of fertile tillers}

The numbers fertile tillers $\mathrm{m}^{-2}$ was significantly affected by the main effects of different herbicidal application as well as the seed rates. The interaction of herbicides with different levels of seed rates were also significant .Maximum number of fertile tillers $\left(133.33 \mathrm{~m}^{-2}\right)$ were recorded from the combined application of 150 $\mathrm{kg} \mathrm{ha}^{-1}$ seed rate with Pallas 45 OD while the minimum number of fertile tillers was recorded at weedy check plots (Table - 7 ). 
Table 7. The effects of seed rates and herbicides on number of fertile tillers in wheat Herbicides Seed rates $\mathrm{kg} \mathrm{ha}^{-1}$

\begin{tabular}{llll} 
& 100 & 150 & 200 \\
\hline Agro 2,4- D 720 g/l & $128.33^{\mathrm{DE}}$ & $129.66^{\mathrm{bcDE}}$ & $130^{\mathrm{bcD}}$ \\
Pallas 45 OD & $131.66^{\mathrm{ABc}}$ & $133.33^{\mathrm{A}}$ & $132.33^{\mathrm{Ab}}$ \\
Derby 175 SC & $128.66^{\mathrm{cDE}}$ & $129^{\mathrm{cDE}}$ & $126.66^{\mathrm{E}}$ \\
Lancolet 450 WG & $126.66^{\mathrm{E}}$ & $128^{\mathrm{dE}}$ & $127^{\mathrm{dE}}$ \\
Weedy check & $35^{\mathrm{g}}$ & $85^{\mathrm{F}}$ & $82^{\mathrm{F}}$ \\
\hline LSD (1\%) & & & \\
CV(\%) & & & \\
\hline
\end{tabular}

Means followed by the same letter in the uppercase with in rows and the same letter in the lower case with in columns are not significantly different from each other at $1 \%$ level of significance

The combined use of all herbicides along with increased seed rates from $100 \mathrm{~kg} \mathrm{ha}^{-1}$ to $200 \mathrm{~kg} \mathrm{ha}^{-1}$ statistically showed that no significant difference. Correspondingly, the application of $100 \mathrm{~kg} \mathrm{ha}^{-1}$ seed rate with $2,4-\mathrm{D} 720$ g/l, Pallas 45 OD and Derby 175 SC caused statistically no significant difference. Furthermore, the application of $150 \mathrm{~kg} \mathrm{ha}^{-1}$ seed rate with all herbicides except Pallas 45 OD showed that statistically non-significant. The combined use of $200 \mathrm{~kg} \mathrm{ha}^{-1}$ with 2, 4 - D $720 \mathrm{~g} / 1$ and Pallas 45 OD caused statistically no significant difference and also the combined use of $200 \mathrm{~kg} \mathrm{ha}^{-1}$ seed rate with Derby $175 \mathrm{SC}$ and Lancolet $450 \mathrm{WG}$ resulted no significant difference. The maximum number of fertile tillers at $150 \mathrm{~kg} \mathrm{ha}^{-1}$ seed rate with Pallas 45 OD could be related with lower dry biomass of weeds, better weed control efficiency that resulted in less inter and intra specific completion of weeds with crop plants for water, nutrients and other growth factors and also due to the optimum space for wheat plants to flourish and produce fertile tillers up to their potential but the probable reason of lower number of fertile tillers in other interaction could be grasses escaped from their phytotoxicity and were competitive with wheat resulting in lower tillers. Lower number of fertile tillers in weedy check treatment can be attributed to higher weed density that resulted in competition for plant growth resources.

Dalga (2016) reported similar results that under low competition between weeds and crop for resources that enhanced productive tillers. Asad et al. (2017) also stated that increase in number of fertile productive tillers relatively better weed control which ultimately facilitated by more translocation of photosynthate towards reproductive growth due to lower weed wheat competition. Hussein et al. (2013) also reported that effective weed control methods could reduce dry matter of weed and increased number of wheat productive tillers.

\section{Number of seeds per spike}

The main effects of different herbicides application and different levels of seed rates had no significant effect on number of seeds per spike but the combined use of different levels of seed rates with different herbicides application was highly influenced the number of seeds per spike. Maximum numbers of seeds per spike were counted at application of with $150 \mathrm{~kg} \mathrm{ha}^{-1}$ seeding rate with Pallas $45 \mathrm{OD}(76.58)$ which was followed by interaction effects of 200kg ha-1 with Pallas 45 OD (73.08). Minimum number of grains per spike was counted from $100 \mathrm{~kg}$ $\mathrm{ha}^{-1}$ seed rate at the weedy check plot which was 54.83 (Figure - 1).

The application of Derby $175 \mathrm{SC}$ with all seed rates showed statistically no significant difference and also application of Derby $175 \mathrm{SC}$ and Lancolet $450 \mathrm{WG}$ showed that no significant difference results. The highest number of seeds per spike at $150 \mathrm{~kg} \mathrm{ha}^{-1}$ seed rate with Pallas 45 OD might be related to lower dry weed biomass, better weed control efficiency that contributed to the crop to have longer spike-lets for producing more number of seeds. Lower number of seeds per spike can be attributed to shorter spike length in weedy check plots due to severe crop-weed competition. 


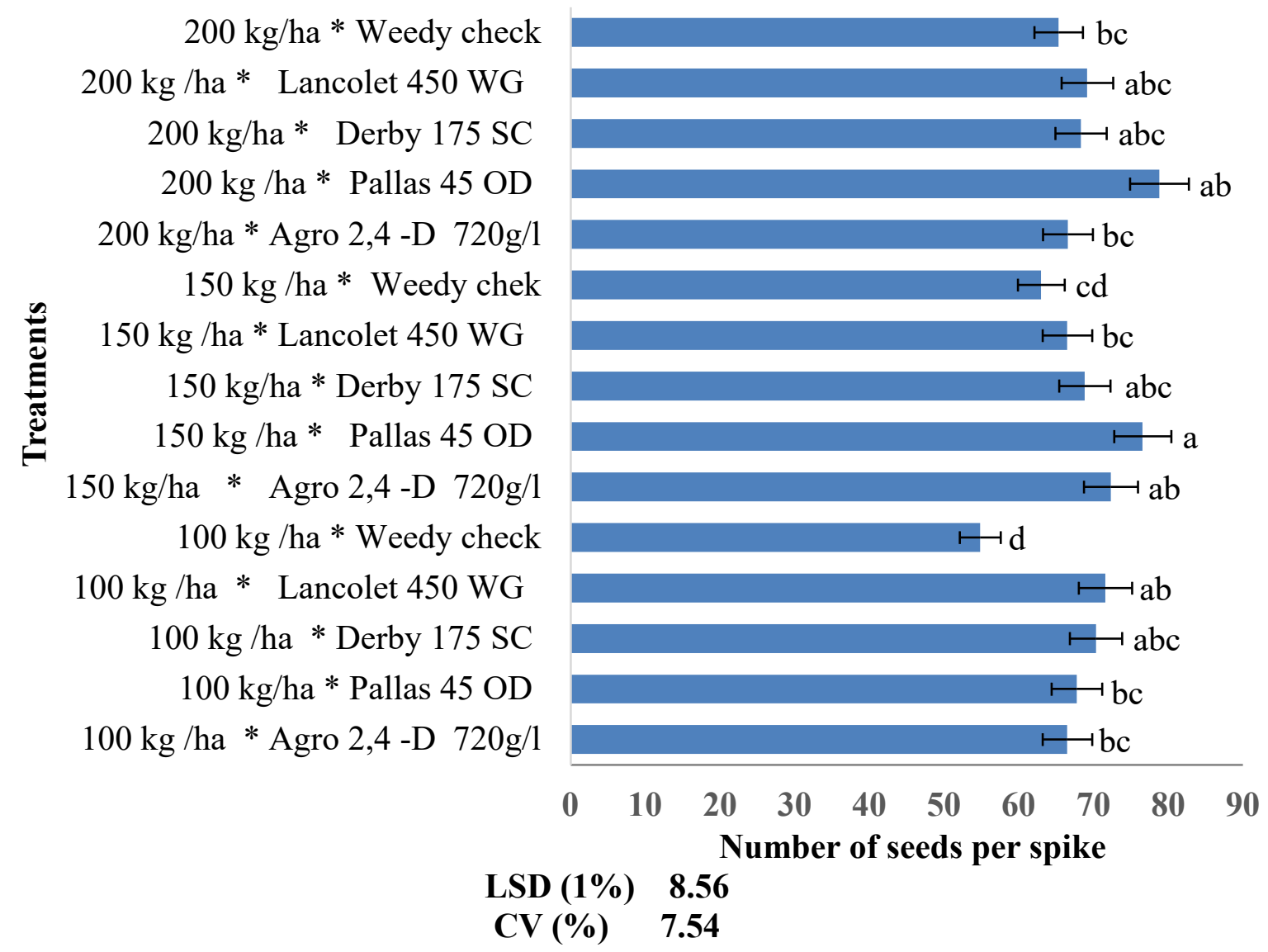

Means followed by the same letter in the lower case with in column chart are not significantly different from each other at $1 \%$ level of significance

Figure 1. The effects of seed rates and herbicides on number of seeds per spike in bread wheat

Similar results have also been reported by Pandey et al. (2007) increase in number of grains per spike can be attributed to availability of nutrients and greater spike length of wheat. According to Ali et al. (2014) the number of seeds per spike increased with decreased weed competition. The poor grain filling due to presence of weeds was reported to be due to reduced tillering, ear formation, and stem weight and height reduction in wheat (Fazal et al., 2012).

\section{Thousand grain weight}

The application of different levels of seed rates did not impose significant effect on thousand grain weight but the use of different herbicides and the combined use of seed rates with herbicides had a significant effect on thousand grain weight. Maximum thousand grain weight was recorded at application of Pallas $45 \mathrm{OD}$ with $150 \mathrm{~kg} \mathrm{ha}^{-1}$ seed rate (44.36 gm) followed by combined use of Pallas $45 \mathrm{OD}$ with $200 \mathrm{~kg} \mathrm{ha}^{-1}$ seed rate $(42.6 \mathrm{gm})$ while minimum number of thousand grain weight was recorded at weedy check (Table - 8).

Table 8.The effects of seed rates and herbicides on thousand grain weight (gm) in bread wheat

\begin{tabular}{llll}
\hline Herbicides & \multicolumn{3}{c}{ Seed rates kg ha } \\
\cline { 2 - 4 } & 100 & 150 & 200 \\
\hline Agro2,4 -D 720 g/l & $39.86^{\mathrm{BC}}$ & $40.66^{\mathrm{BC}}$ & $41.2^{\mathrm{BC}}$ \\
Pallas 45 OD & $41.2^{\mathrm{bc}}$ & $44.36^{\mathrm{a}}$ & $42.6^{\mathrm{ab}}$ \\
Derby 175 SC & $42^{\mathrm{abC}}$ & $41.06^{\mathrm{bC}}$ & $39.06^{\mathrm{C}}$ \\
Lancolet 450 WG & $41.73^{\mathrm{aBc}}$ & $41.6^{\mathrm{aBc}}$ & $39.86^{\mathrm{B}}$ \\
Weedy check & $31.86^{\mathrm{e}}$ & $36^{\mathrm{d}}$ & $28.40^{\mathrm{f}}$ \\
\hline LSD (5\%) & 3.03 & & \\
CV (\%) & 4.61 & & \\
\hline
\end{tabular}

Means followed by the same letter in the uppercase with in rows and the same letter with in columns in the lower case are not significantly different from each other at $5 \%$ level of significance

The ANOVA result showed that the interaction of 2, 4-D $720 \mathrm{~g} / 1$ with all seed rates caused statistically no significant difference and also application of Lancolet $450 \mathrm{WG}$ with $100 \mathrm{~kg} \mathrm{ha}^{-1}$ and $150 \mathrm{~kg} \mathrm{ha}^{-1}$ seed rates showed 
no significant differences. The highest thousand grain weight at $150 \mathrm{~kg} \mathrm{ha}^{-1}$ seed rate with Pallas 45 OD could be related to lower dry weed biomass, better weed control efficiency, minimum intra and inter-specific competition that enable the crop to utilize resources efficiently to produce well vigor seeds but at weedy check treatments lowest number of thousand grain weight was due to higher competition of plant growth resources that resulted in less vigor seeds.

Similar results from Pandey et al. (2007) reported that lower thousand grain weight in weedy check and availability of nutrients and better plant growth might be the reason for heavier grains in high fertilizer levels.

\section{Grain yield}

The grain yield was significantly affected by the application of different levels of seed rates and herbicides application. The interaction effects of different seed rates with different herbicides were also highly significant. Maximum grain yield was obtained at combination of Pallas 45 OD with $150 \mathrm{~kg} \mathrm{ha}^{-1}$ seed rate $\left(4516.42 \mathrm{~kg} \mathrm{ha}^{-1}\right)$ followed by interaction of Pallas 45 OD with $200 \mathrm{~kg} \mathrm{ha}^{-1}$ seed rate $\left(4346.58 \mathrm{~kg} \mathrm{ha}^{-1}\right)$ while minimum grain yield $\left(1025 \mathrm{~kg} \mathrm{ha}^{-1}\right)$ was obtained from the combination of $100 \mathrm{~kg} \mathrm{ha}^{-1}$ seed rate with weedy check (Table - 9).

Table 9.The effects of seed rates and herbicides on grain yield $\left(\mathrm{kg} \mathrm{ha}^{-1}\right)$ in bread wheat

\begin{tabular}{llll}
\hline Herbicides & \multicolumn{3}{c}{ Seed rates kg ha } \\
\cline { 2 - 4 } & 100 & 150 & 200 \\
\hline Agro2,4 -D 720 g/l & $3745.17^{\mathrm{G}}$ & $4033.67^{\mathrm{d}}$ & $3858.17^{\mathrm{ef}}$ \\
Pallas 45 OD & $3813.17^{\mathrm{fG}}$ & $4516.42^{\mathrm{a}}$ & $4346.58^{\mathrm{b}}$ \\
Derby 175 SC & $3838.83^{\mathrm{efG}}$ & $4176.5^{\mathrm{C}}$ & $4053.83^{\mathrm{D}}$ \\
Lancolet 450 WG & $3928.25^{\mathrm{e}}$ & $4210.08^{\mathrm{C}}$ & $4034.75^{\mathrm{D}}$ \\
Weedy check & $1025^{\mathrm{i}}$ & $1243.33^{\mathrm{h}}$ & $1348.33^{\mathrm{h}}$ \\
\hline LSD $(1 \%)$ & & & \\
CV $(\%)$ & 105.37 & & \\
\hline
\end{tabular}

Means followed by the same letters in the upper case with in columns are not significantly different from each other at $1 \%$ level of significance

The application of Derby $175 \mathrm{SC}$ and Lancolet $450 \mathrm{WG}$ with $150 \mathrm{~kg} \mathrm{ha}^{-1}$ seed rate showed that statistically no significant difference and also interaction of $200 \mathrm{~kg} \mathrm{ha}^{-1}$ seed rate with Derby $175 \mathrm{SC}$ and Lancolet $450 \mathrm{WG}$ caused statistically no significant difference. The increased seed rates from $100 \mathrm{~kg} \mathrm{ha}^{-1}$ to $150 \mathrm{~kg} \mathrm{ha}^{-1}$ with interaction of all herbicides showed significant increase in grain yield. The highest number of grain yield at 150 $\mathrm{kg} \mathrm{ha}^{-1}$ seed rate with Pallas 45 OD could be related to less weed competition with crop for plant growth factors and optimum space for wheat plants to flourish and produce fertile tillers up to their potential, more number of seeds per spike, thousand grain weight and higher number of total biomass production. The herbicide also had the ability of controlling various weed species and persistent. However, the lower grain yield at weedy check treatments was due to the severe inter and intra specific competition that resulted in lower yield and yield components.

The result of this study was similar with Nadeem et al. (2006) which stated that different herbicidal treatments had a significant effect on grain yield of wheat. The greatest reduction of yield was occurred when no herbicide was applied. Increased in yield in herbicides treated plots were due to the efficient weed control and thus the crop utilized all the available resources. These results are in confirmation with the work of Tunio et al. (2004) who reported that herbicidal treatments significantly increased grain yield in wheat. Ali et al. (2014) also stated that maximum grain yield was at weed free due to less weed population, better nutrient and water use efficiency but minimum at weedy check.

\section{Biological yield}

The main effects of seed rates and herbicides application highly influenced biological yield. The biological yield was also highly influenced by the interaction effects of seed rates with herbicides . The maximum biological yield was obtained from the combination of Pallas $45 \mathrm{OD}$ with $150 \mathrm{~kg} \mathrm{ha}^{-1}$ seed rate $\left(13100 \mathrm{~kg} \mathrm{ha}^{-1}\right)$ followed by the interaction of Pallas $45 \mathrm{OD}$ with $200 \mathrm{~kg} \mathrm{ha}^{-1}$ seed rate $\left(12100 \mathrm{~kg} \mathrm{ha}^{-1}\right)$. However, minimum biological yield (4566.7 $\mathrm{kg} \mathrm{ha}^{-1}$ ) was obtained from interaction of $100 \mathrm{~kg} \mathrm{ha}^{-1}$ seed rate with weedy check (Table - 10).

Table 10.The effects of seed rates and herbicides on biological yield $\left(\mathrm{kg} \mathrm{ha}^{-1}\right)$ in bread wheat

\begin{tabular}{|c|c|c|c|c|}
\hline \multirow{2}{*}{\multicolumn{2}{|c|}{ Herbicides }} & \multicolumn{3}{|c|}{ Seed rates $\mathrm{kg} \mathrm{ha}^{-1}$} \\
\hline & & 100 & 150 & 200 \\
\hline Agro 2,4 - & $0 \mathrm{~g} / \mathrm{l}$ & $7483.3^{\mathrm{H}}$ & $9580^{\mathrm{ef}}$ & $7900^{\text {gh }}$ \\
\hline Pallas 45 & & $7700^{\mathrm{gH}}$ & $13100^{\mathrm{a}}$ & $12100^{\mathrm{ab}}$ \\
\hline Derby 175 & & $7900^{\mathrm{gH}}$ & $11466.7^{\mathrm{BCd}}$ & $10433.3^{\mathrm{DE}}$ \\
\hline Lancolet 4 & & $8693.3^{\mathrm{fg}}$ & $11583.3^{\mathrm{BC}}$ & $10566.7^{\mathrm{Cde}}$ \\
\hline Weedy ch & & $4566.7^{\mathrm{j}}$ & $5450^{\mathrm{ij}}$ & $5750^{\mathrm{i}}$ \\
\hline $\operatorname{LSD}(1 \%)$ & 1084.4 & & & \\
\hline $\mathrm{CV}(\%)$ & 7.26 & & & \\
\hline
\end{tabular}


Means followed by the same letter in the upper case with in columns and lower case with in rows are not significantly different from each other at $1 \%$ level of significance

The combined use of $100 \mathrm{~kg} \mathrm{ha}^{-1}$ seed rate with Pallas 45 OD and Derby $175 \mathrm{SC}$ exhibited statistically no significant differences. Similarly, the interaction of $150 \mathrm{~kg} \mathrm{ha}^{-1}$ seed rate with Derby $175 \mathrm{SC}$ and Lancolet 450 WG revealed that statistically no significant difference. Moreover, the interaction of $200 \mathrm{~kg} \mathrm{ha}^{-1}$ seed rate with Derby $175 \mathrm{SC}$ and Lancolet $450 \mathrm{WG}$ revealed that statistically no significant difference. The general results showed that increased in biological yield as seed rates increased from 100 to $150 \mathrm{~kg} \mathrm{ha}^{-1}$ seed rates by all herbicides application. The higher number of biological yield at $150 \mathrm{~kg} \mathrm{ha}^{-1}$ seed rate with Pallas 45 OD related to less weed competition with crop plants for water, nutrients and other growth factors and due to the optimum space for wheat plants to flourish and produce fertile tillers up to their potential, more number of seeds per spike and thousand grain weight that contributed to biological yield. However, the lowest biological yield at weed check signified severe competition of weeds resulted in fewer number of plants in plots.

Therefore, it can be concluded that higher seeding rate should be used in combination with broad spectrum herbicide that limited weed growth in the field and increase biological yield. Similar results were reported from Ali and Awan (2004) who stated that decreasing the biological yield in wheat might be due to weed competition as a consequence of depletion of nutrient supply and water by weeds, which resulted in reduced growth, seed and straw yields of crop plants. However, it is suggested that high seed rates were found to increase yield in well watered conditions, whereas the reverse was true with low soil moisture (Marwat et al., 2011).weed control methods increased biological yield of wheat reducing the weed infestation ( Zahoor et al.,2012).

\section{Harvest index}

The main effects of different seed rates and different herbicides and their interaction showed highly significant effect on harvest index. The highest harvest index was observed at interaction of $200 \mathrm{~kg} \mathrm{ha}^{-1}$ seed rate with 2,4-D $720 \mathrm{~g} / \mathrm{l}(35.53 \%)$ closely followed by interaction of $100 \mathrm{~kg} \mathrm{ha}^{-1}$ seed rate with $2,4-\mathrm{D} 720 \mathrm{~g} / \mathrm{l}(33.34 \%)$. The minimum harvest index (18.56\%) was obtained from combination of $150 \mathrm{~kg} \mathrm{ha}^{-1}$ with weedy check (Figure - 2).

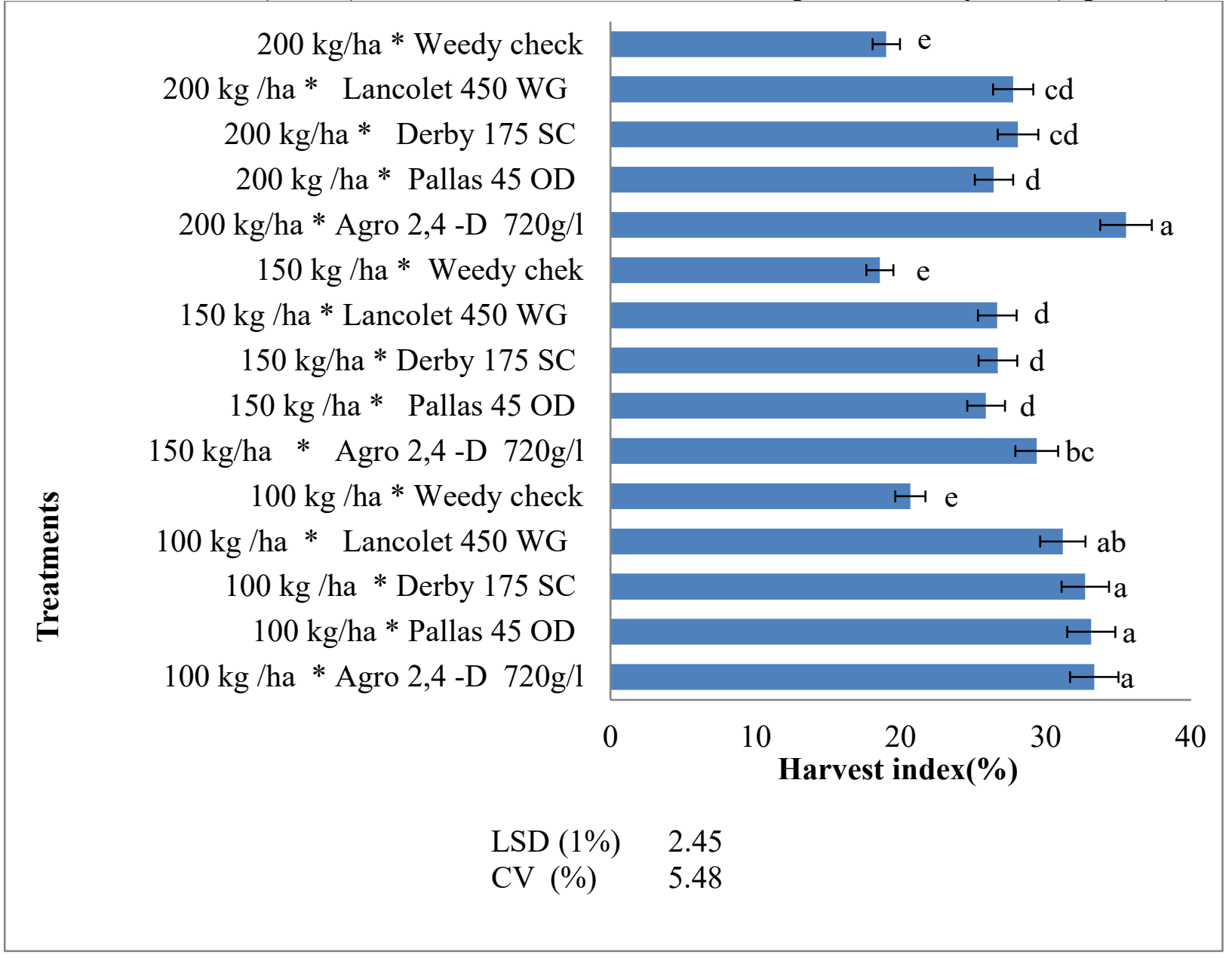

Means followed by the same letter in the lower case with in column chart are not significantly different from each other at $1 \%$ level of significance

Figure 2. The effects of seed rates and herbicides on harvest index (\%) in bread wheat 
The application of $100 \mathrm{~kg} \mathrm{ha}^{-1}$ seed rate with 2,4 -D $720 \mathrm{~g} / 1$, Pallas 45 OD and Derby $175 \mathrm{SC}$ showed that no significant differences and also the combined effects of Pallas $45 \mathrm{OD}$ with 150 and $200 \mathrm{~kg} \mathrm{ha}^{-1}$ exhibited statistically no significant differences. The maximum number of harvest index at higher seed rate of $200 \mathrm{~kg} \mathrm{ha}^{-1}$ in combination with 2, 4-D might be related to higher in total biomass production. The result also clearly indicated that harvest index was lower at higher total biomass production. Similar findings were reported from Ali et al.(2014) and Amare et al.(2014) concluded that harvest index increased with decreased in weed competition. Sujoy et al. (2006) was also reported that significant variation in harvest index of wheat due to weed control treatments. Yield loss

The main effects of seed rates, herbicides and their combined effects were highly significant at on yield loss of bread wheat. The combined effects of using $150 \mathrm{~kg} \mathrm{ha}^{-1}$ seed rate with Pallas $45 \mathrm{OD}$ gave no significant yield loss as compared to other interactions and also minimum yield loss was obtained from the interaction effects of $200 \mathrm{~kg}$ $\mathrm{ha}^{-1}$ with Pallas 45 OD (3.75\%). The combined effects of $100 \mathrm{~kg} \mathrm{ha}^{-1}, 150 \mathrm{~kg} \mathrm{ha}^{-1}$ and $200 \mathrm{~kg} \mathrm{ha}^{-1}$ seed rates with weedy check plots gave higher yield loss which was $77.3 \%, 72.46 \%$ and $70.14 \%$ respectively(Figure -3 ).

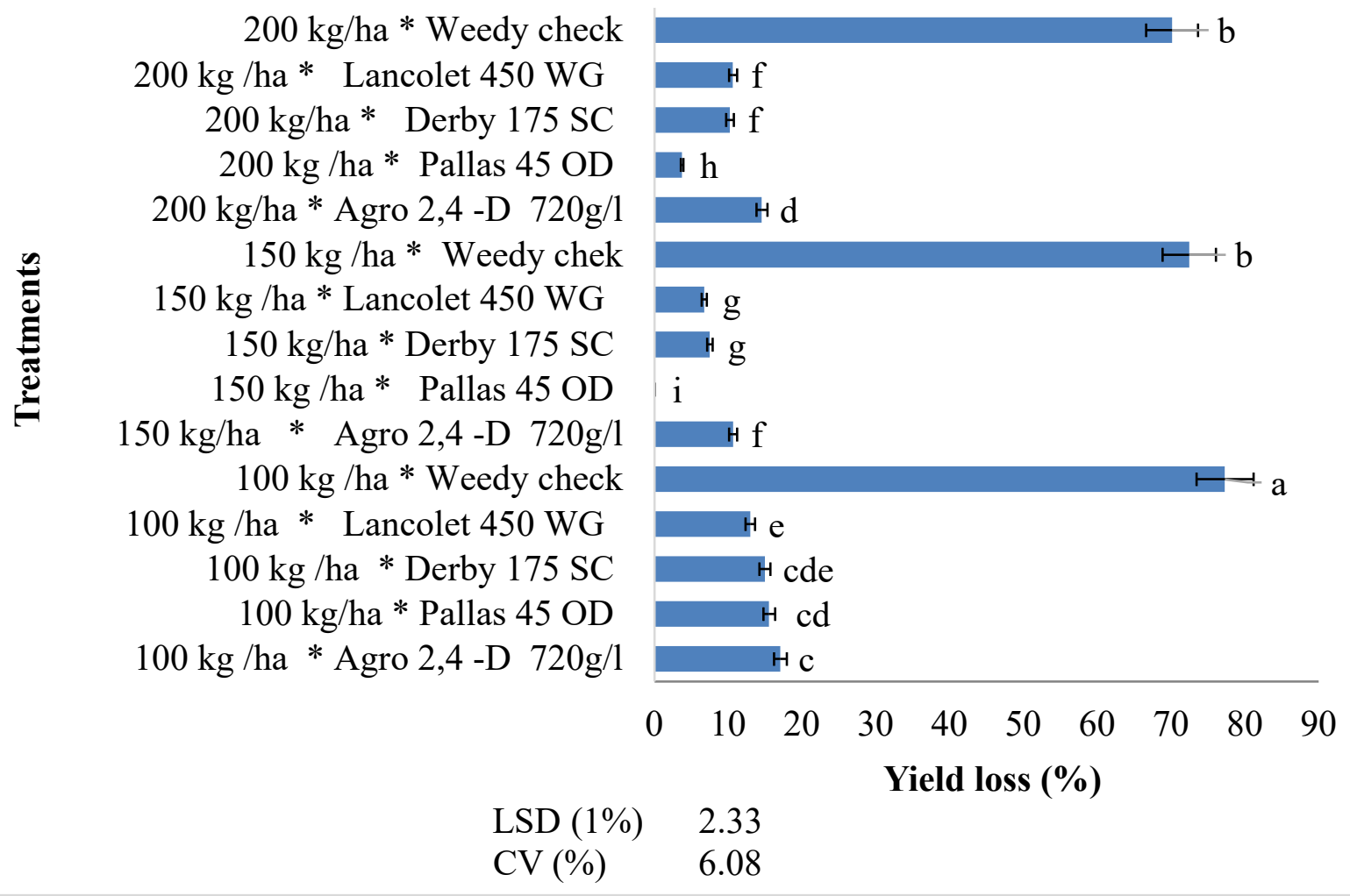

Means followed by the same letter in the lower case with in column chart are not significantly different from each other at $1 \%$ level of significance

Figure 3. The effects of seed rates and herbicides on yield loss $(\%)$ in bread wheat

The application of $100 \mathrm{~kg} \mathrm{ha}^{-1}$ seed rate with Derby $175 \mathrm{SC}$ and Lancolet $450 \mathrm{WG}$ resulted no significant differences. Similarly, application of $200 \mathrm{~kg} \mathrm{ha}^{-1}$ seed rate with Derby $175 \mathrm{SC}$ and Lancolet $450 \mathrm{WG}$ revealed no significant differences. The lowest yield loss at $150 \mathrm{~kg} \mathrm{ha}^{-1}$ seed rate with Pallas 45 OD could be related to higher weed control efficiency, more number of yield components and better crop growing conditions to produce higher yield. In contrast, higher weed biomass resulted in greatest yield reduction due to competition for growth resources and fewer number of wheat in the plots.

The highest yield loss obtained from weedy check plots as a result of higher weed density and competition. The finding was in conformity with the work of Amare et al.(2014) reported that highest yield loss was at weedy check and under poor weed control. On the other hand, Karlen et al. (2002) reported a yield reduction as high as $80 \%$ in wheat due to weed competition throughout the crop growing season.

\section{Correlation analysis}

The simple correlation analysis among most of the traits were statistically highly significant (Table-11).Dry weed biomass was positively $(\mathrm{P}<0.01)$ correlated with yield loss but negatively related with weed control efficiency, number of tillers, number of seeds per spike, thousand grain weight, grain yield and biological yield. The correlation result also indicated that weed control efficiency was positively correlated with number of tillers, seeds per spike, thousand grain weight, grain yield and biological yield. The yield loss was negatively correlated with yield and yield components except weed dry biomass. The number of tillers had positively correlated with number 
of seeds per spike, thousand grain weight, grain yield and biological yield. The number of seeds per spike had positive relationship with thousand grain weight, grain yield and biological yield.

Table 11.The correlation analysis of weed parameters, yield and yield components and yield loss in bread wheat at Holeta 2018/19 main cropping season

\begin{tabular}{|c|c|c|c|c|c|c|c|c|c|}
\hline Traits & DBL & DGW & WCE & TILL & SPS & TGW & YLD & BY & YL \\
\hline DBL & 1 & & & & & & & & \\
\hline DGW & $0.71 * *$ & 1 & & & & & & & \\
\hline WCE & $-0.98 * *$ & $-0.70 * *$ & 1 & & & & & & \\
\hline TILL & $-0.96^{* *}$ & $-0.67 * *$ & $0.92 * *$ & 1 & & & & & \\
\hline SPS & $-0.60 * *$ & $-0.53 *$ & $0.58 * *$ & $0.63 * *$ & 1 & & & & \\
\hline TGW & $-0.80 * *$ & $-0.55^{*}$ & $0.85 * *$ & $0.81 * *$ & $0.53 *$ & 1 & & & \\
\hline YLD & $-0.98 * *$ & $-0.74 * *$ & $0.99 * *$ & $0.93 * *$ & $0.58 * *$ & $0.85^{*}$ & 1 & & \\
\hline BY & $-0.76^{* *}$ & $-0.78 * *$ & $0.76^{* *}$ & $0.72 * *$ & $0.58 *$ & $0.70 *$ & $0.83 *$ & 1 & \\
\hline YL & $0.98 * *$ & $0.74 * *$ & $-0.99 * *$ & $-0.93 * *$ & $-0.58 * *$ & $-0.85^{* *}$ & $-1 * *$ & $-0.83 * *$ & 1 \\
\hline $\begin{array}{l}\text { ** indica } \\
\text { DGW=dr } \\
\text { TGW=th } \\
\text { Economi } \\
\text { Fixed co } \\
\text { recorded } \\
\text { of Ethiop } \\
\text { followed } \\
\text { (7.24) wa } \\
\text { weedy ch } \\
\text { ha }^{-1} \text { seed }\end{array}$ & $\begin{array}{l}\text { significa } \\
\text { oiomass o } \\
\text { sand grair } \\
\text { analysis } \\
\text { were not } \\
\text { m the int } \\
\text { birr } 548 \\
200 \mathrm{~kg} \mathrm{~h} \\
\text { obtained } \\
\text { k plots. T } \\
\text { e with } 2 \text {, }\end{array}$ & $\begin{array}{l}\text { at } 1 \%, \\
\text { rass wee } \\
\text { veight, } G \\
\text { onsidered } \\
\text { action of } \\
7.70 \text { ha }^{-1} \\
{ }^{-1} \text { seed rat } \\
\text { m interac } \\
\text { highest } \\
\text { D (Table- }\end{array}$ & $\begin{array}{l}\text { ignificant } \\
\text { WCE }=\mathrm{w} \\
\text { =grain yie } \\
\mathrm{n} \text { this stu } \\
0 \mathrm{~kg} \mathrm{ha}^{-1} \\
\text { as gained } \\
\text { with Palla } \\
\text { on of Lan } \\
\text { rginal rat }\end{array}$ & $\begin{array}{l}5 \%, \mathrm{NS} \\
\text { ed control } \\
\mathrm{BY}=\text { bio } \\
\text { and the } \\
\text { ed rate w } \\
\text { om } 150 \\
45 \text { OD } 0 . \\
\text { let } 450 \\
\text { f return }\end{array}$ & $\begin{array}{l}\text { on-signif } \\
\text { fficiency, } \\
\text { gical yiel } \\
\text { ghest tot } \\
\text { Pallas } 4 \\
\text { ha }^{-1} \text { see } \\
\text { ha }^{-1}(48 \\
\text { with } 10 \\
.89) \text { was }\end{array}$ & $\begin{array}{l}\text { ant, } \mathrm{DBL}= \\
\mathrm{ILL}=\text { num } \\
\text { and } \mathrm{YL}=\mathrm{y} \\
\text { variable } \\
\mathrm{OD} 0.5 \mathrm{~L} \\
\text { ate with } \\
4.80 \mathrm{birr} \\
\mathrm{kg} \mathrm{ha}^{-1} \mathrm{se} \\
\text { tained fro }\end{array}$ & $\begin{array}{l}\text { dry bion } \\
\text { er of till } \\
\text { eld loss } \\
\text { st Ethi } \\
\mathrm{a}^{-1} \text { wher } \\
\text { allas } 45 \\
\left.\mathrm{a}^{-1}\right) \text {. The } \\
d \text { rate } \mathrm{w} \\
\mathrm{n} \text { the int }\end{array}$ & $\begin{array}{l}\text { ass of bro } \\
\mathrm{s}, \mathrm{SPS}=\mathrm{s} \\
\text { pian birr } \\
\text { as the hig } \\
\text { D } 0.5 \mathrm{~L} \mathrm{r} \\
\text { ighest be } \\
\text { ile the mi } \\
\text { action eff }\end{array}$ & $\begin{array}{l}\text { af weeds, } \\
\text { per spike, } \\
\text { ha }^{-1} \text { was } \\
\text { het return } \\
\text { hich was } \\
\text { cost ratio } \\
\text { m was at } \\
\text { of } 150 \mathrm{~kg}\end{array}$ \\
\hline
\end{tabular}


Table 12.The economic analysis of seed rates and herbicides types on adjusted grain yield and gross benefit on bread wheat in 2018/19 main cropping season

\begin{tabular}{|c|c|c|c|c|c|c|c|}
\hline Treatments & $\begin{array}{c}\text { Average } \\
\text { Yield (kg } \\
\left.\text { ha }^{-1}\right)\end{array}$ & $\begin{array}{l}\text { Adjusted } \\
\text { yield } \\
\left(\mathrm{kg} \mathrm{ha}^{-1}\right)\end{array}$ & $\begin{array}{c}\text { GB } \\
\left(\text { Birr ha }^{-1}\right)\end{array}$ & $\begin{array}{l}\text { TVC } \\
(\text { Birr } \\
\left.\mathrm{ha}^{-1}\right)\end{array}$ & $\begin{array}{c}\text { NB } \\
\left(\text { Birrha }^{-1}\right)\end{array}$ & MRR & $\mathrm{B}: \mathrm{C}$ \\
\hline $100 \mathrm{~kg} * 2,4-\mathrm{D} 720 \mathrm{~g} / 1$ & 3745.17 & 3370.65 & 50559.75 & 7084 & 43475.75 & 78.83 & 7.14 \\
\hline $100 \mathrm{~kg} *$ Pallas 45 OD & 3813.17 & 3431.85 & 51477.75 & 8384 & 43093.75 & 20.38 & 6.14 \\
\hline $100 \mathrm{~kg} *$ Derby $175 \mathrm{SC}$ & 3838.83 & 3454.95 & 51824.25 & 7524 & 44300.25 & 42.31 & 6.89 \\
\hline $100 \mathrm{~kg} *$ Lancolet $450 \mathrm{WG}$ & 3928.25 & 3535.43 & 53031.45 & 7284 & 45474.45 & 57.97 & 7.24 \\
\hline $100 \mathrm{~kg} *$ weedy check & 1025.00 & 922.50 & 13837.50 & 6624 & 7213.50 & 0.00 & 2.09 \\
\hline $150 \mathrm{~kg} * 2,4-\mathrm{D} 720 \mathrm{~g} / \mathrm{l}$ & 4033.67 & 3630.30 & 54454.50 & 7784 & 46670.50 & 80.89 & 7.00 \\
\hline $150 \mathrm{~kg} *$ Pallas 45 OD & 4516.42 & 4064.78 & 60971.70 & 9084 & 54887.70 & 25.81 & 7.00 \\
\hline $150 \mathrm{~kg} *$ Derby175SC & 4176.50 & 3758.85 & 56382.75 & 8224 & 48158.75 & 43.00 & 6.90 \\
\hline $150 \mathrm{~kg} *$ Lancolet $450 \mathrm{WG}$ & 4210.08 & 3789.07 & 56836.05 & 7984 & 48852.05 & 59.68 & 7.10 \\
\hline $150 \mathrm{~kg} *$ weedy check & 1243.33 & 1119.00 & 16785.00 & 7324 & 9461.00 & 0.00 & 2.30 \\
\hline $200 \mathrm{~kg} * 2,4-\mathrm{D} 720 \mathrm{~g} / 1$ & 3858.17 & 3472.35 & 52085.25 & 8484 & 43601.25 & 72.65 & 5.20 \\
\hline $200 \mathrm{~kg} *$ Pallas 45 OD & 4346.58 & 3911.92 & 58678.80 & 9784 & 48894.80 & 22.00 & 6.00 \\
\hline $200 \mathrm{~kg} *$ Derby $175 \mathrm{SC}$ & 4053.83 & 3648.45 & 54726.75 & 8924 & 45802.75 & 39.58 & 6.13 \\
\hline $200 \mathrm{~kg} *$ Lancolet $450 \mathrm{WG}$ & 4034.75 & 3631.28 & 54469.20 & 8684 & 45785.20 & 53.95 & 6.27 \\
\hline $200 \mathrm{~kg} *$ weedy check & 1348.33 & 1213.50 & 18202.50 & 8024 & 10178.50 & 0.00 & 2.27 \\
\hline
\end{tabular}

The cost of variable inputs were described as: cost of pallas $45 \mathrm{OD}=3400 \mathrm{ETB} / \mathrm{L}$, cost of Agro 2,4-D 720 g/l =400 $\mathrm{ETB} / \mathrm{L}$, cost of Derby $175 \mathrm{SC}=8400 \mathrm{ETB} / \mathrm{L}$, cost of lancolet $450 \mathrm{WG}=18,181.80 \mathrm{ETB} / \mathrm{kg}$, Spraying cost $=60 \mathrm{ETB} /$ ha, cost of Urea $=1280 \mathrm{ETB} / 100 \mathrm{~kg}$ and cost of NPS=1440 ETB/100kg. The field labor cost for sowing, harvesting, threshing and transportation 50 labors/ha each at 38 ETB per person net income was the product of market price and adjusted grain yield.

The higher number of marginal rate of return was obtained from the application of 2, 4-D at all seed rates combinations as compared to other interactions. The relative net returns increased with increasing seed rates with application herbicides that was probably due to better control of weeds that consequently resulted in increased grain yield. Furthermore, interaction of higher seed rates with herbicides showed that better relative returns over lower seed rate with herbicides application as the result of better weed management. The similar result was reported from Babu et al. (2017) and Kalid et al., (2014) suggested that herbicides combinations with higher seed rates effectively controlled weed infestation in bread wheat and gave higher yield that related directly with high relative net return. All interaction of seed rates and herbicides application gave higher net benefit over weedy checks.

\section{SUMMARY AND CONCLUSION}

Bread wheat is one of major food grains that contain different nutrient and cultivated from small to large scale farmers in Ethiopia. Weed management practices such as optimum seed rates and promising herbicides are among the important methods for the management of weeds to improve wheat production and productivity. The integrated weed management practices such as optimum seed rates and herbicides nowadays advantageous than using single weed management practices for good weed control as well as obtaining maximum yield. Therefore, this study was designed to investigate the effects of seed rates and post emergence herbicides application on weed growth and productivity of wheat.

All of the traits studied were significantly affected by the interaction of different levels of seed rates with herbicides application. The minimum number of weed density, dry biomass of weeds and weed control efficiency were recorded at interaction of $150 \mathrm{~kg} \mathrm{ha}^{-1}$ seed rate with Pallas 45 OD but no weed control at weedy check while the maximum numbers of weed density and dry biomass were obtained from weedy checks. The maximum number of productive tillers, seeds per spike, thousand grain weight, grain yield and biological yield were obtained from the combined effects of $150 \mathrm{~kg} \mathrm{ha}^{-1}$ seed rate with Pallas $45 \mathrm{OD}$. The combined use of $200 \mathrm{~kg} \mathrm{ha}^{-1}$ seed rate with Pallas 45 OD resulted in maximum spike length. The biological yield and grain yield increased significantly with the increase of seed rates. The maximum harvest index was observed at interaction of lower seed rate with 2, 4-D. Dry weed biomass was positively related with yield loss but negatively related with other traits studied. The grain yield was positively correlated with yield components but has a negative relationship with that of dry biomass of weeds.

The combined effects of using $150 \mathrm{~kg} \mathrm{ha}^{-1}$ seed rate with Pallas 45 OD gave non-significant yield loss as compared to other interactions and also minimum yield loss was calculated from the interaction effects of $200 \mathrm{~kg}$ $\mathrm{ha}^{-1}$ with Pallas 45 while highest yield loss was obtained at weedy check plots. The maximum variable cost was obtained from using of $200 \mathrm{~kg} \mathrm{ha}^{-1}$ seed rate with Pallas 45 OD due expensive costs of inputs. The maximum net 
benefit was gained from the combined use higher seed rates of $150 \mathrm{~kg} \mathrm{ha}^{-1}$ with Pallas 45 OD closely followed by $200 \mathrm{~kg} \mathrm{ha}^{-1}$ with Pallas 45 OD than using lower seed rates. The maximum benefit cost ratio was obtained from the interaction effects of $100 \mathrm{~kg} \mathrm{ha}^{-1}$ seed rate with Lancolet $450 \mathrm{WG}$.

The use of higher seed rates was effective as compared to lower seed rate $100 \mathrm{~kg} \mathrm{ha}^{-1}$ for weed control and obtaining maximum yield. The herbicides having the ability of controlling various weed species gave better yield advantages as well as for good weed management over narrow spectrum herbicides. Pallas 45 OD is recommended for controlling various weed species in wheat field at small scale and commercial farms. The combined use of seed rate of $150 \mathrm{~kg} \mathrm{ha}^{-1}$ with Pallas $45 \mathrm{OD}$ effectively managed weeds, economical and gave maximum yield. However, more yield advantages obtained from using interaction of $150 \mathrm{~kg} \mathrm{ha}^{-1}$ seed rate with application of broad spectrum herbicides Pallas 45 OD. Since the experiment was conducted for one season and location, it should be repeated over seasons or multiple locations for best recommendation.

\section{REFERENCES}

Abdulkerim, J. Tana ,T. and Eticha,T.,2015 .Response of Bread Wheat(Triticum aestivum L.) Varieties to Seeding rates at Kulumsa, South Eastern Ethiopia. Asian Journal of Plant Sciences, 14:50-58.

Ahmad, K.,Z., Shah, Khan, M. K. and Khan, M.Q.,1993.Effect of post - emergence herbicides application and hand weeding on wheat and weed pressure. Pakistan Journal of Weed Science Research, 6 (1-2): 40-45.

Akhtar, M.Q., Hamayoun, M.B., Gill and Nazir,M.S.,1991.Comparative Study of various crop management practices on the weed growth and wheat yield. Sarhad Journal of Agriculture, 7(2): 91-94.

Ali, Y. and Awan, A.R.,2004. Influence of salinity at seedling stage on yield and yield components of different rice lines. International Journal of Biotechnology, 1: 175-179.

Ali,H., Tahir, M. and Nadeem,M.A.,2014.Determining Critical Period of Weed Competition in Wheat under Different Tillage Systems.life,12(2):74-79.

Amare,T.,Sharma,J.J. and Zewdie,K.,2014.Effect of weed control methods on weeds and wheat (Triticum aestivum L.) yield. World journal of agricultural research, 1(2):124-128.

Asad, M., Safdar, A., Ansar, M.R.,Ijaz, A., Suhaib, M. and Abuzar, M.K., 2017. Weed and Wheat Dynamics Preceding Different Herbicide. Pakistan Journal of Agricultural Research, 30(4):346-355.

Ashiq, Muhammad, N. and Ahmad,N.,2007.Comparative efficacy of different herbicides against broadleaved weeds in wheat. Pakistan Journal of Weed Science Research, 13(3-4):149-156.

Babu, R.S.K.,Kakraliya, Prakash,L.,Kumar,P. and Yadav,R.A.,2017.Effect of Plant Geometry and Seed Rates on Growth, Yield Attributes, Productivity As Well As Weed Dynamics of Wheat (Triticum aestivum L.). International Journal of Current Microbiology and Applied Science, 6(3): 81-88.

Bibi,S.,Marwat, K.B., Hassan, G. and Khan,N.M.,2008.Effect of herbicides and wheat population on control of weeds in wheat. Pakistan. Journal of Weed Science Research, 14 (3-4):111-119.

Birhanu, K., 1985. Progress of weed management in wheat production in Ethiopia.In: Regional Wheat Workshop for Eastern, Central and Southern Africa and Indian Ocean. Njoro, Kenya. Sept. 2-5,CIMMYT, Nairobi, Kenya :95-102.

Cimmyt, M. and Cimmyt, M., 1988. From agronomic data to farmer recommendations: An economics training manual. CIMMYT., ISBN :8-28.

CSA.2018.Agricultural Sample Survey Series : Report on Area and Production for Major Crops(Private Holdings, Main Season).Statistical Bulletin No.586.Centeral Statistics Agency of Ethiopia, Addis Ababa, Ethiopia.:1530.

Dalga, D.,2016. Weed Dynamics and Yield of Bread Wheat (Triticum aestivum L.) in response to weed management and nitrogen fertilizer rates in Southern Ethiopia. Scientia, 16 (1): 8-19.

Davasenapathy,PT,Remesh,B.,2008.Efficiencyindices for Agricultural ManagementResearch. New Indian Publishing Agency, New Delhi India: 576-64.

Fazal, Munsif, Kawsar,Ali, Iftikhar and Khan,H.U., 2012.Efficacy of various herbicides against weeds and their impact on yield of spring wheat. Pakistan Journal of Weed Science Research, 15(2-3): 191-198

Frehiwot, G., Girma ,F. and Haile ,D., 2012. Verification test of Pyroxsulam to control weeds of wheat in Bale High lands: Ethiopian Journal of Weed Management, 5: 73-76

Gomez,K.A.and Gomez ,A.A.,(1984).Statistical procedures for agricultural research (2 ed.). John wiley and sons, NewYork, pp. 680.

Haile, D. and Girma,F.,2010.Integrated Effect of Seeding Rate, Herbicide Dosage and Application Timing on Durum Wheat (Triticum Turgidum L. Var Durum) Yield, Yield Components and Wild Oat (Avena Fatua L.) Control in South Eastern Ethiopia. Ethiopian Journal of Science, 2:12-26.

Hussain,Z.,Marwat,K.B.,Munsif,F.,Samad,A.and Ali,K.,2013.Evaluation of various herbicides and their combinations for weed control in wheat crop. Pakistan Journal of Botany, 45(1) :55-59.

Karlen, L.D., Buhler, D.D., Ellusbury, M.M. and Andrews, S.S., 2002. Soil, weeds and insect management strategies for sustainable agriculture. Journal of Biological Science, 2(1) :58-62. 
Khalid,M.S.,Saleem, M.F.,Ali, S.,Pervez,M.W.,Rehman,M., Hussain,S. and Rehman,K.,2014. Optimization of nitrogen fertilizer level for newly evolved wheat (Triticum aestivum) cultivars. Applied Science Report, 3: 83-87.

Marwat, K.B., Saeed, M.,Hussain,Z.,Gul, B. and Rashid,H.,2008. Study of various herbicides for weed control in wheat under irrigated conditions. Pakistan Journal of Weed Science Research,14 (2):1-8

Marwat,K.B., Khan,A,.M ,Hashim,S.,Nawab,K.And Abdul Mateen,K.K.,2011.Integrated Weed Management In Wheat Pakistan Journal of Botany, 43(1):625-633.

Marwat,K.S.,Usman,K., Khan,N.,Khan,U.M., Ejaz Ahmad Khan,A.E., Khan,A.M., Rehman,U.A.,2013. Weeds of Wheat Crop and Their Control Strategies in Dera Ismail Khan District, Khyber Pakhtun Khwa, Pakistan .American Journal of Plant Sciences, 4: 66-76.

Mathewos, A.,Tewodros,M. and Yasin,G.,2012. Participatory on-farm evaluation of improved bread wheat technologies in some districts of southern Ethiopia. Journal of Biology, Agriculture and Healthcare, 2(4): 8591.

Megersa , K., Geleta, G., Tigist „B., and Chemeda. B., 2017. Influence of post-emergence herbicides on major grass weeds and wheat (Triticum aestivum L.) at Gedo and Shambo, Western Oromia .Communications in Plant Sciences: 1-7

Merga, B. and Ahmed, A., 2019. A Review on Agricultural Problems and Their Management in Ethiopia. Turkish Journal of Agriculture-Food Science and Technology, 7(8):1189-1202.

Munsif,F., Ali,K.,Khan,I., Khan,H.U.and Anwar,M.,2009.Efficacy of various herbicides against weeds and their impact on yield of maize. Pakistan Journal of Weed Science Research, 15(2-3):191-198.

Nadeem,M.A.,Ali,A. and Tanveer,A.S.I.F.,2006. Effect of different weed control practices and fertilizer levels on the weeds and grain yield of wheat. Pakistan Journal of Botany, 39(1):173.

Pandey, I.B. and Dwivedi,D.K.,2007.Effect of planting pattern and weed-control methods on weed growth and performance of wheat (Triticum aestivum). Indian Journal of Agronomy, 52 (3) : 235-238.

Rezene,F.,1985. Review of weed science research activities in wheat and barley. In:A Review of Crop Protection Research in Ethiopia. Tsedeke Abate (Ed.),IAR, Addis Ababa, Ethiopia. :121-148.

Stroud,A. and Parker,C.,1989.A weed identification guide for Ethiopia. A weed identification guide for Ethiopia : $55-78$.

Sujoy, D.,Sarkar,A.K.,Bhattacharya,S.P.,Abhijit, S. 2006.Effect of various weed management practices in wheat. Environment and Ecology, 24: 620-622.

Tana,T.,Lemlem,M.and Dejene,M.,2018.Determination of Critical Period of Weed Competition in Bread Wheat Triticum aestivum L.at Haramaya,Eastern Ethiopia ,Doctoral dissertation,Haramaya University:1-92

Tanner,D.G and Grief,S.,1991.Weed control research conducted on wheat in Ethiopia. pp. In:Wheat Research in Ethiopia: AHistorical Perispective.Hailu Gebre-Mariam, Tnner, D.G. and Mengistu, H. (Eds,). IAR/CIMMYT.Addis Ababa, Ethiopia : 235-276.

Tunio, S.D.,Kaka, S.N.,Jarwar, A.D.,Wagan, and M.R.,2004.Effect of integrated weed management practices on wheat yield. Pakistan Journal of Agriculture Engineering and Veterinary Science, 20 (1):5-10.

USDA,2019.World Agricultural Production and Agricultural projections. Oxford University Press.pp.32

Zahara ,M. and Shugute,A.,2017.Evaluation of Sequential Application of Herbicides for Broad and Grass Weed Management in Durum Wheat, Ethiopia. American Journal of Environmental and Resource Economics, 1:3236.

Zahoor, F., Malik, M.A., Mehmood, K.,Rasheed,M.,Ansar,R.,Hussain, M.,Kazmi,M.H. and Jamil, M.,2012.Optimizing herbicide use in wheat (Triticum aestivum L.) under rain-fed conditions. African Journal of Agricultural Research, 7(35) :4858-4866.

Zegeye, T., Taye,G., Tanner,D., Verkuiji, H., Agidie, A. and Mwangi,W.2001.Adoption of improved bread wheat varieties and inorganic fertilizer by small-scale farmers in Yelmana Densa and Farta districts of Northwestern Ethiopia.. In Proceedings of the First International Congress of Wheat EARO and CIMMYT. Mexico City,Mexico :315 - 566. 